This report was prepared as an account of work sponsored by an agency of the United States Government. Neither the United States Government nor any agency thereof, nor any of their employees, makes any warranty, express or implied, or assumes any legal liability or responsibility for the accuracy, completeness, or usefulness of any information, apparatus, product, or process disclosed, or represents that its use would not infringe privately owned rights. Reference herein to any specific commercial product, process, or service by trade name, trademark, manufacturer, or otherwise does not necessarily consitute or imply its endorsement, recommendation; or favoring by the United States Government or any agency thereof. The views and opinions of authors expressed herein do not necessarily state or reflect those of the United States Government or any agency thereof.

\title{
THE DEVELOPMENT AND FIELD TESTING OF A SYSTEM FOR DETERMINATION OF ULTRAFINE ACTIVITY PARTICLE SIZE DISTRIBUTION AND WORKING LEVELS
}

\author{
Final Report
}

October 31, 1990

Contract No. DE FG02 89ER60876

Prepared for the Office of Health and Environmental Research U.S. Department of Energy

By

Philip K. Hopke

Department of Chemistry

Clarkson University

Potsdam, N.Y. 13699-5810 


\begin{abstract}
Recent investigations of radon decay products in indoor air have shown that what has been called the "unattached" fraction is in fact an ultrafine size aerosol with diameters in the range of 0.5 to $10 \mathrm{~nm}$. There are a number of difficulties in characterizing particles in this size range. Classical diffusion batteries using screens with high mesh numbers do not have the resolution to give detailed information for the ultrafine range. The use cf single screens of differing mesh numbers (Graded Screen Arrays) either in parallel or in a stacked configuration can be used to provide these results. However, accurately measuring the activity directly attached to the screens is difficult because of the attachment of some activity to the back side of the screen and the distribution of activity around the individual screen wires. A continuous monitoring system that provides information on both the size and charge distributions on these important size range particles has been constructed and its behavior characterized in the laboratory. It has now been field tested and employed in several field studies to determine the exposure of individuals to radon progeny in the indoor environment.
\end{abstract}




\section{INTRODUCTION}

The infiltration of radon into the indoor environment may cause the exposure of the public to excessive umounts of radioactivity. The potential public health risk posed by the decay products of ${ }^{22} \mathrm{Rn}$ are now considered as significant enough to warrant increased study of their occurrence and properties. The NCRP (NCRP, 1984a) estimated that even including medical xrays, the majority of the annual average dose from radioactivity to the general population is due to radon decay products. The dose of ionizing radiation to the bronchial epithelium is estimated to cause about $20 \%$ of the non-smoking related lung cancer deaths in the United States (NCRP, 1984b). The properties of the decay products including their diffusivity and attachment to airborne particles are important considerations in the assessment of the health risks posed by radon progeny. It was the purpose of this project to develop improved measurement methodologies to provide better information on the behavior of the decay products in the environment as well as to provide a comprehensive review of prior measurements. This review was published this year (Hopke, 1990a).

The fact that the "unattached" fraction is not a single entity, but represents a variable ultrafine mode in the activity size distribution is be juming clear. There is, however, very little available data on the nature of the ultrafine paricicle mode aerosol with respect to its size distribution or particle charge. In particular there is no continuous series of measurements of the airborne radioactivity concentration and the fraction of that activity in the ultrafine or "unattached" mode of the activity size distribution. Such measurement could be used to relate these variables to the activities in the home such as cooking, smoking, running appliances, etc., that might affect the ambient aerosol concentrations and hence the quantities that directly produce the radioactive dose to the occupants.

\section{SEMI-CONTINUOUS GRADED SCREEN ARRAY SYSTEM}

During the last several years, there has been a significant improvement in our understanding of the behavior of the ${ }^{218}$ Po species immediately following its formation from the decay of ${ }^{222} \mathrm{Rn}$. It $\dot{2}$ now known that the "unattached" fraction of the airborne radioactivity is really associated with an ultrafine or nuclei mode in the particle size distribution (Reineking and Porstend8rfer, 1986). It has also been shown that the size of this mode can be affected by the concentration of reactive trace gas in the air (Hopke et al., 1988). There has also been substantial developments in the theoretical understanding of the penetration of particles through 
wire screens (Cheng and Yeh, 1980; Cheng et al., 1980; Yeh et al., 1982, Ramamurthi and Hopke, 1989). Holub and Knutson (1987) have shown that methods involving single wire screens can be useful in elucidating particle size information. These methods have adapted the concepts of conventional diffusion batteries measuring the activity size distribution over the range of particles diameters $>0.5 \mathrm{~nm}$. These systems have been termed as "Graded Screen Arrays" (GSA). Thus, we now have the understanding to develop a measurement system to determine both the concentration and size distribution of the airborne radioactivity over the range of particle sizes from $0.5 \mathrm{~nm}$ to $350 \mathrm{~nm}$.

The original design and conceptual framework for this system has been previously presented (Hopke, 1986; Kulju et al., 1986). The final design of the automated, semi-continuous GSA system has been described by Ramamurthi and Hopke (1990a). The measurement system involves the use of 6 sampler-detector units. The design of a sampler-detector unit is shown in Figure 1. Screens are wrapped around the sampler covering the slit except for the one sampler that is left open to measure the total concentration. The characteristics of the 6 samplers are presented in Table 1.

Table 1. Design and operating parameters for the optimized measurement system.

\begin{tabular}{clllc}
\hline Unit & $\begin{array}{l}\text { Sampler } \\
\text { Slit Width } \\
(\mathrm{cm})\end{array}$ & $\begin{array}{l}\text { Sampler } \\
\text { Diameter } \\
(\mathrm{cm})\end{array}$ & $\begin{array}{l}\text { Wire Screen } \\
\text { Mesh x Turns }\end{array}$ & $\begin{array}{c}\mathrm{d}_{\mathrm{p}}(50 \%) \\
(0.5-500 \mathrm{~nm} \text { range }) \\
(\mathrm{nm})\end{array}$ \\
\hline 1 & 0.5 & 5.3 & - & - \\
2 & 0.5 & 5.3 & 145 & 1.0 \\
3 & 0.5 & 5.3 & $145 \times 3$ & 3.5 \\
4 & 0.5 & 5.3 & $400 \times 12$ & 13.5 \\
5 & 1.0 & 12.5 & $635 \times 7$ & 40.0 \\
6 & 1.0 & 12.5 & $635 \times 20$ & 98.0 \\
& & & \\
Sampling flow rate $=$ & 15 lpm (each unit) & & \\
Detector-Filter separation $\approx 0.8 \mathrm{~cm}$ (all units) &
\end{tabular}




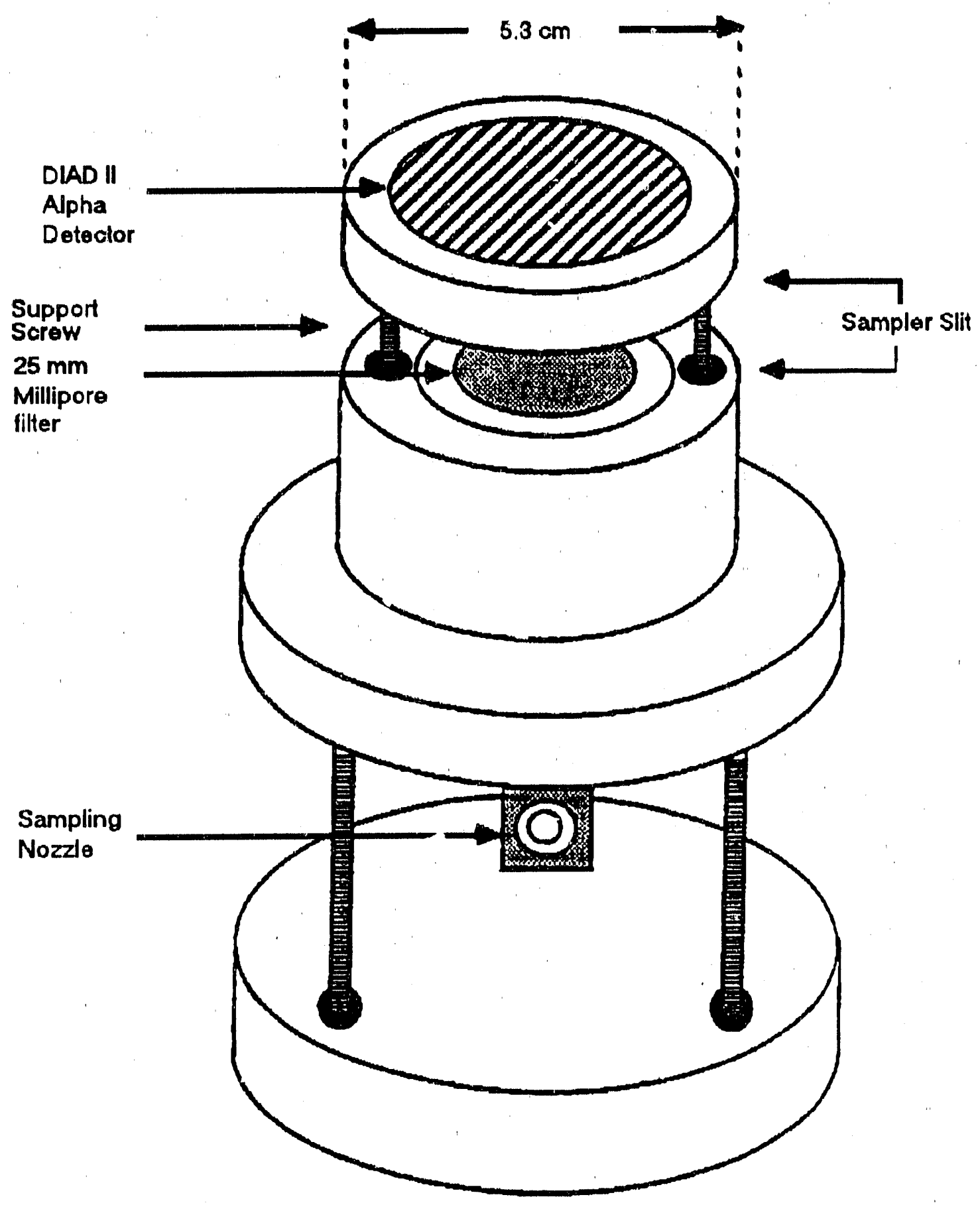

Figure 1. Sampler-detector unit in the measurement system. 
The operation of the system involves the sampling of air simultaneously through all the units at independent flow rates (parallel operation). The sampled air is drawn through the wire screen(s) and the sampler slit between the detector and filter sections in each unit (Figure 1). The sampled air is drawn through a $25 \mathrm{~mm}$ filter positioned in the filter holder assembly. Each sampler-detector unit is thus an independent stage that separates the airborne activity based on its atmospheric diffusion coefficient which is in turn, related to the particle size. The signal from the alpha detectors in each of the sampler-detector units is connected through an amplifier into an 8segment multiplexer, and then are routed to a multichannel buffer into an IBM-PC based multichannel analyzer. Details of the electronic instrumentation, connections and set-up are presented by Ramamurthi (1989).

The counts associated with the two alpha peaks (Po-218 and Po-214) are calculated from the alpha spectra after background subtraction. Given the knowledge of the penetration characteristics of each GSA stage and the measured detection efficiency of each sampler, the activity size distributions can then be calculated from the observed stage activities using the reconstruction algorithms described by Ramamurthi and Hopke (1990b).

\section{ACTIVITY-WEIGHTED SIZE DISTRIBUTION MEASUREMENTS}

The automated system was field tested in September 1989 in a house in the Princeton, N.J. area in a collaborative effort with the C.E.E.S. group at Princeton University. The system worked well. The results of this field trial was reported by Ramamurthi and Hopke (1990a). However, the initial design required that the screens be removed in order to change the filter. This procedure was quite time consuming and so the samplers were modified to permit easy removal of the filter holder from the bottom of the unit so that the filter can now be easily replaced.

The system has subsequently be utilized in three series of experiments. The first measurements were in the basement of a house in Springfield, PA. The second set of studies were conducted on the first floor of an unoccupied house in Princeton, N.J. and the third series of studies were made on the first floor of an occupied home in Northfield, CT. These studies have been described in detail by $\mathrm{Li}$ (1990a) and partially presented in a series of presentations at meetings (Li et al., 1990 b \& c; Hopke et al., 1990 b-f). Several papers are currently being prepared for submission to appropriate journals describing these studies. 
The systems has produced sufficient interest that we are currently making similar systems for Battelle Pacific Northwest Laboratories and the Office of Radiation Programs of the Environmental Protection Agency. We plan to continue our studies of the activity size distributions in typical indoor atmospheres as part of the new Department of Energy grant (DE FG02 90ER61026) that began July 1, 1990.

\section{PROJECT PERSONNEL}

\section{Principal Investigator}

Philip K. Hopke, Robert A. Plane Professor of Chemistry

\section{Associate Research Scientist}

Mukund Ramamurthi, July 1, 1989 to December 31, 1989.

Research Associate

Piotr Wasiolek, March 15, 1990 to June 30, 1990.

\section{Graduate Students}

Chih-Shan Li, July 1, 1989 to June 30, 1990. Ph.D. awarded September 1990.

Ketan Shah, M.S. student in Chemistry, September 1989 to June 30, 1990.

\section{PUBLICATIONS FROM THIS PROJECT}

M. Ramamurthi and P.K. Hopke, Simulation Studies of Reconstruction Algorithms for the Determination of Optimum Operating Parameters and Resolution of Graded Screen Array Systems (Non-Conventional Diffusion Batteries), Aerosol Sci. Technol. 12:700-710 (1990).

A Measurement System for Rn Decay Froduct Lung Depo:ition Based on Respiratory Models, P.K. Hopke, M. Ramamurthi and E.O. Knutson, Health Phys. 58:291-295 (1990).

Assessment of Wire and Tube Penetration Theories Using $\mathrm{A}^{218} \mathrm{PoO}_{\mathrm{x}}$ Cluster Aerosol, $\mathrm{M}$. Ramamurthi, R. Strydom and P.K. Hopke, J. Aerosol Sci. 21:203-211 (1990).

A Critical Review of Measurements of the "Unattached" Fraction of Radon Decay Products, P.K. Hopke, Department of Energy Report No. DOE/ER-0451P, January 1990.

Size Distribution Measurements of Ultratine Aerosols, $\mathrm{d}_{\mathrm{p}}>1.8 \mathrm{~nm}$, Formed by Radiolysis in a DMA Aerosol Neutralizer, W. Winklmayr, M. Ramamurthi, R. Strydom, and P.K. Hopke, Aerosol Sci. Technol. 13:394-398 (1990).

Li, C.S., P.K. Hopke, and M. Ramamurihi, An Automated, Semi-Continuous System for Measuring Indoor Radon Progeny Activity-Weighted Size Distributions, $D_{p}:$ 0.5-500 NM, 
Proceedings of the 1990 Symposium on the Measurement of Toxic and Related Air Pollutants, Air and Waste Management Association, Pittsburgh, PA, pp. $31-37$ (1990).

The Effect of Air Cleaning on the Size of the Indoor Radioactive Aerosol, P.K. Hopke, C.S. Li, and M. Ramamurthi, in AEROSOLS: Science, Industry, Health, and Environment, S. Masuda and K. Takahashi, eds., Pergamon Press, Inc., pp. 827-832 (1990).

Measurement of the Size Distributions of Radon Progeny in Indoor Air, P.K. Hopke, M. Ramamurthi, and C.S. Li, in AEROSOLS: Science, Industry, Health, and Environment, S. Masuda and K. Takahashi, eds., Pergamon Press, Inc., pp. 842-847 (1990).

An Automated, Semi-Continuous System for Measuring Indoor Radon Progeny Activity-Weighted Size Distributions, $\mathrm{D}_{\mathrm{p}}:$ 0.5-500 nm, M. Ramamurthi and P.K. Hopke, Aerosol Sci. Technol. (in press, 1990).

\section{PRESENTATION OF RESULTS OF THIS PROJECT}

The Measurement of Size Fractions of Radon Progeny, P.K. Hopke, presented at the Technical Measurements Center, operated by UNC Geotech for the Grand Junction Project Office, Grand Junction, Colorado, September 1989.

Verification of Penetration Theories Using A Monodisperse Cluster Aerosol, $(D=0.078 \pm 0.003$ $\mathrm{cm}^{2} / \mathrm{s}, \mathrm{d}_{\mathrm{p}} \approx 0.6 \mathrm{~nm}$ ), M. Ramamurthi and P.K. Hopke, presented at the American Association for Aerosol Research, Reno, NV. October 1989.

DB-CNC Measurements of Radiolytic Ultrafine Aerosol Size Distributions, dp $>5 \mathrm{~nm}, \mathrm{M}$. Ramaniurthi and P.K. Hopke, presented at the American Association for Aerosol Research, Reno, NV. October 1989.

Radon Decay Product Activity Size Distribution Measurement Methods - A Laboratory Intercomparision, M. Ramamurthi, P.K. Hopke, R. Strydom, K.W. Tu, E.O. Knutson, R.F. Holub, W. Winklmayr, W. Marlow and S.C. Yoon, presented at the American Association for Aerosol Research, Reno, NV. October 1989.

An Automated, Semi-Continuous Graded Screen Array (ACS-GSA) System for Indoor Radon Decay Product Activity Size Distribution Measurements, M. Ramamurthi and P.K. Hopke, presented at the American Association for Aerosol Research, Reno, NV. October 1989.

An Automated, Semi-Continuous System for Measuring Indoor Radon Progeny Activity-Weighted Size Distributions, $\mathrm{D}_{\mathrm{p}}$ : 0.5-500 NM, C.S. Li, P.K. Hopke, and M. Ramamurthi, presented at 1990 EPA/A\&WMA International Symposium, April, 1990.

Intercomparisons of Radon Progeny Size Distribution Measurement Techniques in an Underground Research Uranium Mine, M. Ramamurthi, R. Strydom and P.K. Hopke, presented at AAAR 1990 Annual Meeting, PA., June, 1990. 
Field Evaluation and Health Assessment of Air Cleaners in Removing Radon Decay Products, C.S. Li, M. Ramamurthi, P.K. Hopke, K. Gadsby, A. Cavallo and R. Sokolow, presented at AAAR 1990 Annual Meeting, PA., June, 1990.

Particle Size Distribution of Various Ambient Aerosol Sources, K. Shah, W. Li and P.K. Hopke, presented at the American Chemical Society Northeast Regional Meeting, June, 1990.

Air Cleaning and Radon Decay Product Mitigation: A Re-evaluation, P.K. Hopke, C.S. Li and M. Ramamurthi, presented at the 5th International Conference on Indoor Air Quality and Climate, July, 1990.

Measurement of the Size Distributions of Radon Progeny in Indoor Air, P.K. Hopke, M. Ramamurthi and ('S. Li, presented at Third International Aerosol Conference, Kyoto, Japan, September 1990.

The Effect of Air Cleaning on the Size of the Indoor Radioactive Aerosol, P.K. Hopke, C.S. Li, and M. Ramamurthi, presented at Third International Aerosol Conference, Kyoto, Japan, September 1990.

Air Cleaning and Radon Decay Product Mitigation, P.K. Hopke, C.-S. Li, and M. Ramamurthi, presented at the 29th Hanford Symposium, Richland, Washington, October 1990.

Measurement of Size Distributions of Indoor Radioactive Aerosol, presented at the 29th Hanford Symposium, Rïhland, Washington, October 1990.

\section{REFERENCES}

Cheng, Y.S. and H.C. Yeh (1980) Theory of a Screen-Type Diffusion Battery, J. Aerosol Sci. 11:313-320.

Cheng, Y.S., J.A. Keating, and G.M. Kanapilly (1980) Theory and Calibration of a Screen-Type Diffusion Battery, J. Aerosol Sci. 11:549-556.

Hopke, P.K. (1986) Conceptual design of a system to characterize the radioactive ultrafine aerosol, in Indoor Radon, Air ?ollution Control Association, Pittsburgh, PA, pp. 206-215.

Hopke, P.K., K.D. Chu, L.M. Kulju, and M. Ramamurthi (1988) The Initial Behavior of ${ }^{218}$ Po in Indoor Air, Radiat. Prot. Dosim. 24:207-210.

Hopke, P.K. (1990a) A Critical Review of Measurements of the "Unattached" Fraction of Radon Decay Products, Department of Energy Report No. DOE/ER-0451P, 65 pp.

Hopke, P.K., C.S. Li and M. Ramamurthi (1990b) Air Cleaning and Radon Decay Product Mitigation: A Re-evaluation, presented at he 5th International Conference on Indoor Air Quality and Climate, July, 1990. 
Hopke, P.K., C.S. Li, and M. Ramamurthi (1990c) The Effect of Air Cleaning on the Size of the Indoor Radioactive Aerosol, in AEROSOLS: Science, Industry, Health, and Environment, S. Masuda and K. Takahashi, eds., Pergamon Press, Inc., pp. 827-832.

Hopke, P.K., M. Ramamurthi, and C.S. Li (1990d) Measurement of the Size Distributions of Radon Progeny in Indoor Air, in AEROSOLS: Science, Industry, Health, and Environment, $\mathrm{S}$. Masuda and K. Takahashi, eds., Pergamon Press, Inc.,"pp. 842-847.

Hopke, P.K.; C.S. Li, and M. Ramamurthi (1990e) Air Cleaning and Radon Decay Product Mitigation, presented at the 29th Hanford Symposium, Richland, Washington, October 1990.

Hopke, P.K. M. Ramamurthi, and C.-S. Li (1990) Measurement of Size Distributions of Indoor Radioactive Aerosol, presented at the 29th Hanford Symposium, Richland, Washington, October 1990.

Li, C.S. (1990a) Field Evaluation and Health Assessment of Air Cleaners in Removing Radon Decay Products in Domestic Environments, Ph.D. Thesis, University of Illinois at UrbanaChampaign, Department of Energy Report No. DOE ER61029-2.

Li, ¿.S., P.K. Hopke, and M. Ramamurthi (1990b) An Automated, Semi-Continuous System for Measuring Indoor Radon Progeny Activity-Weighted Size Distributions, $D_{\mathrm{p}}:$ 0.5-500 NM, Proceedings of the 1990 Symposium on the Measurement of Toxic and Related Air Pollutants, Air and Waste Management Association, Pittsburgh, PA, pp. 31-37.

Li, C.S., M. Ramamurthi, P.K. Hopke, K. Gadsby, A. Cavallo and R. Sokolow, (1990c) Field Evaluation and Health Assessment of Air Cleaners in Removing Radon Decay Products, presented at AAAR 1990 Annual Meeting, PA., June, 1990.

Kuiju, L.M., M. Ramamurthi, and P.K. Hopke (1986) The detection and measuremert of the activity size distribution of ultrafine particles. Paper No. 86-40.6, Air Pollution Contrcl Association, Pittsburgh, PA.

NCRP (1984a) Exposure from the Uranium Series with Emphasis on Radon and Its Daughters, NCRP Report No. 77, National Council on Radiation Protection and Measurements, Bethesda, MD.

NCRP (1984b) Evaluation of Occupational and Environmental Exposures to Radon and Radon Daughters in the United States, NCRP Report No. 78, National Council on Radiation Protection and Measurements, Bethesda, MD.

Ramamurthi, M. (1989) Detection and Measurement of Ultrafine Activity Size Distributions $\left(d_{p}>\right.$ $0.5 \mathrm{~nm}$ ) Associated with Radon Decay Products, Ph.D. Thesis, University of Illinois at UrbanaChampaign, Department of Energy Report No. DOE ER60669-2.

Ramamurthi, M. and P.K. Hopke (1989) On improving the validity of wire screen "unattached" fraction radon daughter measurements, Health Phys. 52: 189-194. 
Ramamurthi, M. and P.K. Hopke (1990a) An Automated, Semi-Continuous System for Measuring Indoor Radon Progeny Activity-Weighted Size Distributions, $D_{\mathrm{p}}: 0.5-500 \mathrm{~nm}, \mathrm{M}$. Ramamurthi and P.K. Hopke, Aerosol Sci. Technol. (in press).

Ramamurthi, M. and P.K. Hopke (1990b) Simulation studies of reconstruction algorithms for the determination of optimum operating parameters and resolution of graded screen array systems (non-conventional diffusion batteries), Aerosol Sci. Technol. 12:700-710.

Reineking, A. and J. Porstendorrfer (1986) High-volume screen diffusion batteries and $\alpha$ spectroscopy for measurement of the radon daughter activity size distributions in the environment. J. Aerosol Sci. 17:873-879.

Yeh, H.C., Y.S. Cheng, and M.M. Orman (1982) Evaluation of various types of wire screens as diffusion battery cells. J. Colloid Interface Sci. 86:12-16. 

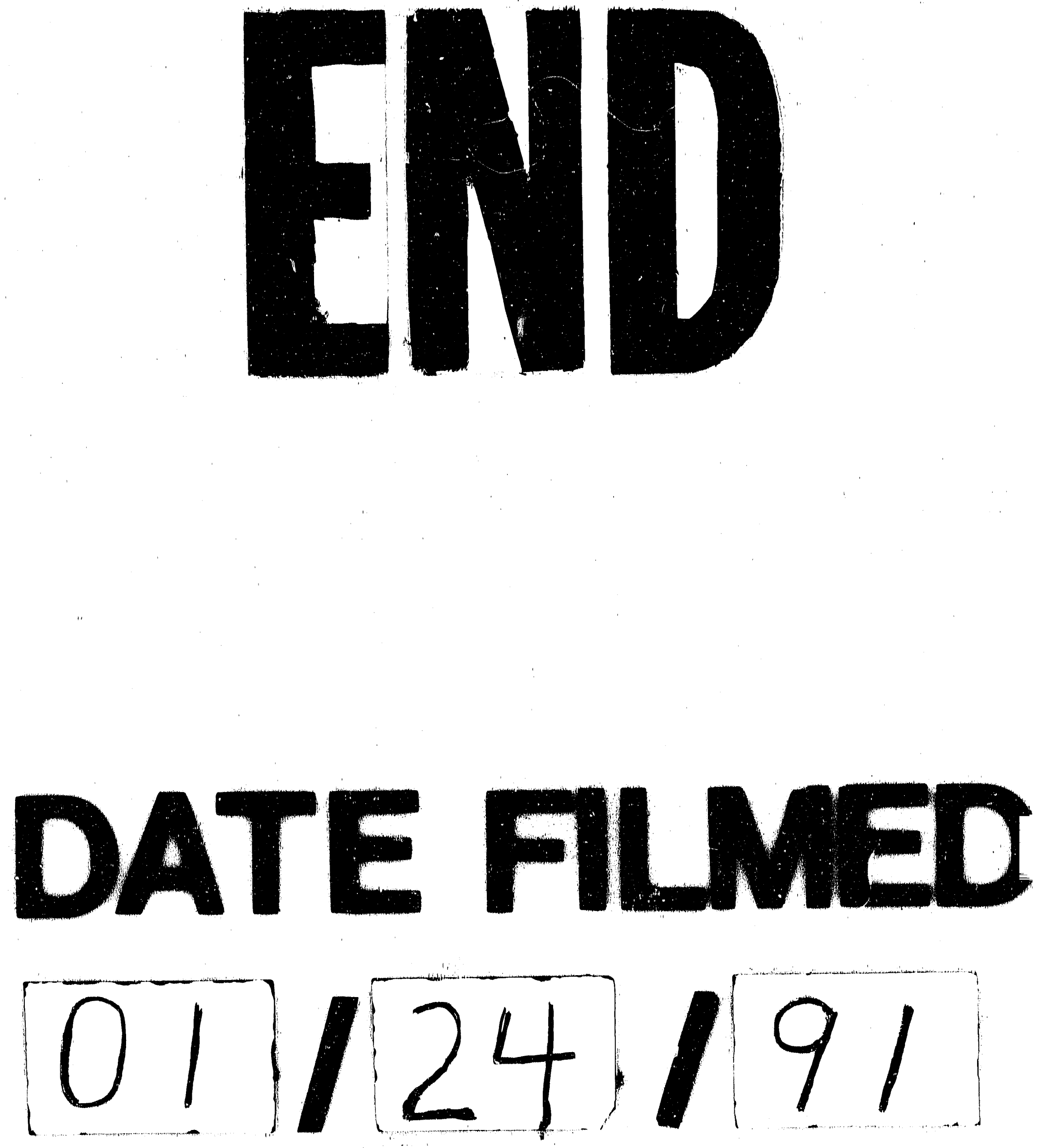